\title{
Prevalensi Penyakit Arteri Perifer Berdasarkan Nilai Ankle-Brachial Pressure Index di Universitas Mulawarman
}

\author{
Muhammad Aminuddin ${ }^{1}$ \\ 1Program Studi D3 Keperawatan Fakultas Kedokteran Universitas Mulawarman \\ aminuddin@fk.unmul.ac.id ${ }^{1}$
}

\author{
Diajukan 25 Desember 2020 Diperbaiki 9 Februari 2021 Diterima 19 Februari 2021 \\ ABSTRAK
}

Latar Belakang: Prevalensi penyakit arteri perifer (PAP) pada tahun 2015 di dunia diperkirakan lebih dari 200 juta orang. Penyakit ini terjadi pada $<0,4$ per 1000 orang pada usia 35-45 tahun dan 6 dari 1000 orang pada usia di atas 65 tahun. Namun prevalensi PAP dan faktor risiko yang mempengaruhi usia remaja sampai saat ini belum tergambarkan dengan jelas.

Tujuan: Mengetahui prevalensi dan faktor risiko penyakit arteri perifer pada mahasiswa fakultas kedokteran Universitas Mulawarman.

Metode: Penelitian ini melibatkan 141 responden dengan teknik pengambilan responden purposive sampling. PAP ditegakkan dengan interpretasi nilai ankle-brachial pressure index (ABPI). Nilai ABPI diukur menggunakan doppler vaskular dan sfigmomanometer, sedangkan faktor risiko diukur menggunakan kuesioner.

Hasil: Penelitian ini mengidentifikasi 52,5\% responden memiliki nilai ABPI normal, 44,7\% mengalami PAP (ringan dan sedang) dan 2,8\% kalsifikasi pembuluh darah. Faktor risiko PAP tidak memiliki hubungan yang bermakna dengan nilai ABPI/PAP dengan $p$ value 0,730 (konsumsi makanan asin), 0,823 (konsumsi manis), 0,718 (minum kopi), 0,445 (merokok), dan 0,981 (aktivitas fisik).

Kesimpulan: Kebiasaan mengkonsumsi makanan asin, makanan manis, minum kopi berlebih, dan kebiasaan merokok serta aktivitas fisik yang kurang dapat menurunkan nilai ABPI atau menjadi faktor risiko terjadinya penyakit arteri perifer.

Kata Kunci: Penyakit Arteri Perifer; ABPI; Mahasiswa

\section{ABSTRACT}

Background: The prevalence of peripheral artery disease (PAD) in the world in 2015 is estimated to be more than 200 million people, occurring at $<0.4$ per 1000 people at the age of 35-45 years and 6 out of 1000 people at the age of 65 years. However, the prevalence of PAD and its risk factors for adolescence have not been clearly delineated.

Objective: Determine the prevalence and risk factors for peripheral artery disease in Mulawarman University medical faculty students.

Method: This study used 141 respondents with a purposive sampling technique of taking respondents. PAD is confirmed by the interpretation of the value of the ankle-brachial pressure index (ABPI). ABPI values were measured using a vascular doppler and a sphygmomanometer. While the risk factors are measured using a questionnaire.

Results: This study identified $52.5 \%$ of respondents as having normal ABPI values, $44.7 \%$ having PAD (mild and moderate), and $2.8 \%$ of blood vessel calcifications. The risk factors for PAD did not have a significant relationship with the ABPI / PAP value with p-value 0.730 (consumption of salty foods), 0.823 (sweet consumption), 0.718 (drinking coffee), 0.445 (smoking) and 0.981 (physical activity).

Conclusion: The habit of consuming salty foods, sweet foods, drinking excess coffee and smoking habits, and inadequate physical activity can reduce the ABPI value or become a risk factor for peripheral artery disease.

Keywords: peripheral artery disease (PAD); ABPI; Student 
PENDAHULUAN

Penyakit arteri perifer (PAP) didefinisikan sebagai penyempitan dan obstruksi aliran anterior dari arteri sistemik utama selain dari sirkulasi otak dan koroner. Ada banyak penyebab PAP termasuk vaskulitis, sindrom displastik, kondisi degeneratif, trombosis, dan tromboemboli (Conte \& Vale, 2018).

PAP pada umumnya disebabkan oleh penyempitan arteri progresif pada ekstremitas bagian bawah, akibat aterosklerosis (Selvin \& Erlinger, 2004). Kondisi ini menyebabkan berbagai sindrom klinis. Secara global, prevalensi PAP dapat ditemukan, baik tanpa gejala maupun dengan gejala. Sebagian besar kasus PAP tidak menunjukkan gejala bervariasi $(0,9 \%$ dan $22 \%)$, tetapi bahkan penyakit yang diam secara klinis menyiratkan peningkatan morbiditas dan mortalitas vaskular (Blanes et al., 2009; Conte \& Vale, 2018).

Penelitian sebelumnya menunjukkan bahwa PAP dikaitkan dengan peningkatan risiko morbiditas dan mortalitas yang signifikan pada penyakit kardiovaskular (Conte \& Vale, 2018; Sartipy et al., 2018; Selvin \& Erlinger, 2004; Velescu et al., 2017). Strategi diagnostik dan perawatan PAP mudah dilakukan dan dapat diterapkan secara luas, tetapi permasalahan PAP tetap belum bisa diselesaikan dengan tuntas. Oleh karena itu, penting untuk mengenali dampak PAP dan mengukur kemampuan yang dapat kita lakukan untuk mengelola pasien PAP ini.

Prevalensi PAP saat ini di dunia diperkirakan lebih dari 200 juta orang, dan $15 \%$ terjadi pada populasi di Australia (Conte \& Vale, 2018; Criqui \& Aboyans, 2015), sedangkan PAP dengan keluhan gejala klinis diperkirakan terjadi pada $<0,4$ per 1000 orang pada usia 35-45 tahun dan 6 dari 1000 orang pada usia di atas 65 tahun (Campia et al., 2019; Criqui \& Aboyans, 2015; Fowkes et al., 2017). Walaupun demikian, prevalensi PAP pada usia remaja sampai saat ini belum ada penelitian yang menggambarkan dengan jelas.

Berbagai macam faktor risiko dapat menyebabkan PAP, antara lain pola hidup seperti merokok, aktivitas fisik, kebiasaan mengkonsumsi makanan asin, makanan manis, dan minum kopi. Kebiasaan ini terbentuk akibat perubahan zaman yang telah memasuki revolusi industri 4.0, termasuk dampaknya pada remaja. Revolusi industri 4.0 memungkinkan para remaja bekerja serba praktis. Salah satu gaya hidup yang dapat menimbulkan risiko terhadap PAP adalah konsumsi makanan siap saji

Berdasarkan hal di atas, PAP dapat terjadi pada usia remaja akibat pola kebiasaan yang tidak sehat dan dapat berdampak buruk berupa meningkatnya morbiditas dan mortalitas akibat PAP. Oleh karena itu, penelitian ini ditujukan sebagai bentuk pencegahan dan dilakukan untuk mengidentifikasi prevalensi PAP serta faktor risiko yang mempengaruhinya pada remaja, khususnya mahasiswa Fakultas Kedokteran Universitas Mulawarman.

\section{METODE}

Jenis penelitian ini adalah deskriptif dengan pendekatan studi cross sectional (studi potong lintang). Hal ini bertujuan untuk menggambarkan prevalensi dan faktor risiko penyakit arteri perifer (PAP) pada remaja.

Penelitian ini melibatkan 141 dari 224 mahasiswa Fakultas Kedokteran Universitas Mulawarman Samarinda semester 1 tahun akademik 2019/2020, dengan teknik pengambilan responden menggunakan purposive sampling sesuai dengan kriteria inklusi antara lain responden adalah mahasiswa aktif Fakultas Kedokteran Universitas Mulawarman semester 1, bersedia menjadi reponden, dan hadir saat hari penelitian.

Pengumpulan data dilakukan pada 
Prevalensi Penyakit Arteri Perifer Berdasarkan Nilai Ankle-Brachial...

Oktober 2019 mengikuti langkah-langkah pengajuan etik penelitian, proses perijinan pada institusi, penentuan sampel, pengisian kuesioner dan pengukuran risiko PAP. Alur pengumpulan data digambarkan seperti gambar 1 .

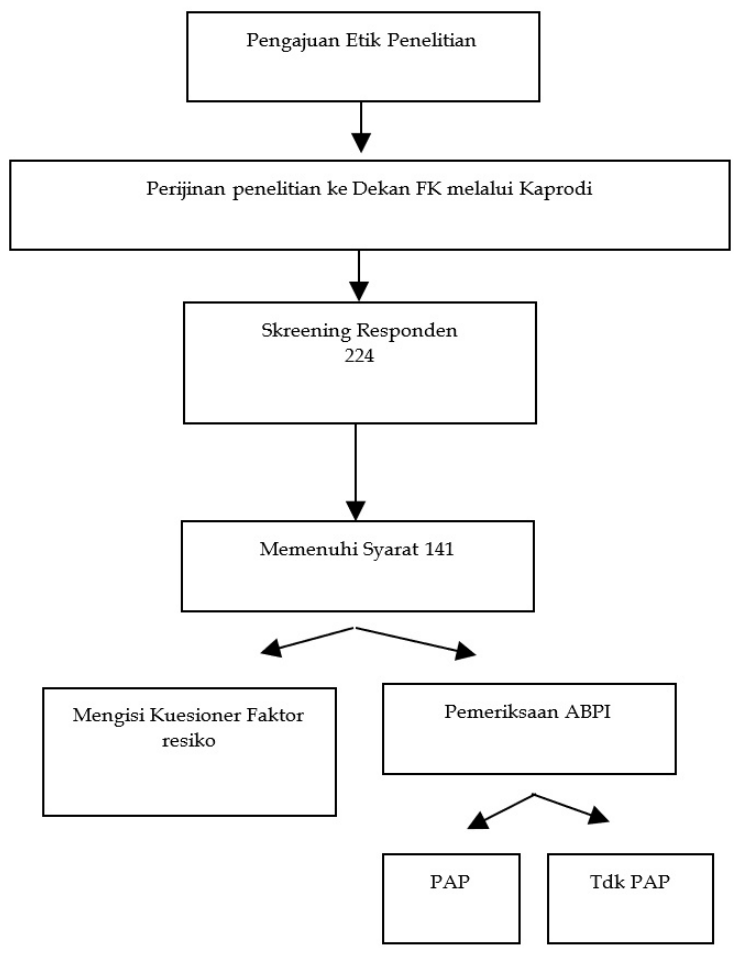

Gambar 1. Alur Penelitian

PAP ditegakkan dengan cara mengukur Ankle-brachial pressure index (ABPI). Nilai ABPI diukur menggunakan dopler vaskular dan sfigmomanometer. Nilai ABPI didapatkan dengan cara membagi nilai tekanan nadi ankle tertinggi yang diukur pada nadi dorsalis pedis dan nadi tibialis posterior, dengan nilai tekanan nadi brachial dengan kategori normal, PAP ringan, sedang, berat, dan kalsifikasi pembuluh darah (Tabel 1) (Sibley III et al., 2017).

PAP ditentukan berdasarkan nilai $\mathrm{ABPI} \leq 0,89$ yang merupakan titik potong terbaik untuk diagnosis PAP (Weragoda et al., 2016). Faktor risiko yang mempengaruhi PAP diukur menggunakan kuesioner yang berisi jenis kelamin, Indeks Massa Tubuh (IMT), perubahan pola hidup seperti merokok, aktivitas fisik, kebiasaan mengkonsumsi makanan asin, makanan manis, dan minum kopi.
Penelitian ini telah mendapatkan lulus uji etik atau ethical clearance dari Komisi Etik Penelitian Kesehatan Fakultas Kedokteran Universitas Mulawarman dengan No. dokumen 168/KEPK-FK/XII/ 2019 tanggal 25 Oktober 2019. Responden yang bergabung dalam penelitian ini mendapatkan penjelasan tentang jalannya penelitian, tindakan yang akan diberikan, dan kerahasian identitas responden. Responden yang bersedia pun telah menandatangani lembar informed consent.

Tabel 1. Interpretasi Nilai ABPI

\begin{tabular}{ccc}
\hline No & Nilai ABPI & Interpretasi \\
\hline 1 & $>1,40$ & Kalsifikasi Pembuluh \\
& & Darah \\
2 & $0,90-1,40$ & Normal \\
3 & $0,70-0,89$ & PAP ringan \\
4 & $0,51-0,69$ & PAP sedang \\
5 & $\leq 0,50$ & PAP berat \\
\hline
\end{tabular}

HASIL DAN PEMBAHASAN

Responden pada penelitian ini mayoritas berjenis kelamin perempuan $(80,1 \%)$ yang berusia 16 sampai dengan 21 tahun. Berdasarkan Indeks Massa Tubuh (IMT), sebagian besar responden penelitian berada pada kategori normal $(62,4 \%)$, walaupun terdapat responden yang memiliki IMT kurus dan obesitas ringan masing masing $27 \%$ dan $9,2 \%$ serta obesitas berat $1,4 \%$ (Tabel 2)

Tabel 2. Distribusi Responden Berdasarkan Karakteristik Responden

\begin{tabular}{|c|c|c|c|}
\hline No & Karakteristik & $\mathbf{F}$ & $\%$ \\
\hline \multicolumn{4}{|c|}{ Jenis Kelamin } \\
\hline & Perempuan & 113 & 80,1 \\
\hline 2 & Laki-laki & 28 & 19,9 \\
\hline \multicolumn{4}{|c|}{ Usia } \\
\hline & 16 tahun & 8 & 5,7 \\
\hline & 17 tahun & 8 & 5,7 \\
\hline & 18 tahun & 22 & 15,6 \\
\hline & 19 tahun & 18 & 12,8 \\
\hline & 20 tahun & 22 & 15,6 \\
\hline & 21 tahun & 17 & 12,1 \\
\hline \multicolumn{4}{|c|}{ Index Massa Tubuh } \\
\hline & Kurus Tingkat Ringan $(17-18,4)$ & 38 & 27 \\
\hline & Normal $(18,5-25)$ & 88 & 62,4 \\
\hline & Obesitas Ringan $(25,1-27)$ & 13 & 9,2 \\
\hline & Obesitas Berat $(>27)$ & 2 & 1,4 \\
\hline
\end{tabular}

\section{Prevalensi PAP}

Penyakit arteri perifer didiagnosis melalui nilai ABPI yang diukur 
Prevalensi Penyakit Arteri Perifer Berdasarkan Nilai Ankle-Brachial...

menggunakan doppler vaskuler dan sfigmomanometer dengan kategori PAP ringan, sedang dan berat. Data penelitian ini menunjukkan 52,5\% responden memiliki nilai ABPI normal, 44,7\% mengalami PAP ringan dan sedang. Selain itu, didapatkan nilai ABPI dengan kategori kalsifikasi pembuluh darah sebanyak 2,8\% (Tabel 3).

Tabel 3. Distribusi Frekuensi Berdasarkan Kategori PAP

\begin{tabular}{clcc}
\hline No & \multicolumn{1}{c}{ Kategori PAP } & F & \% \\
\hline 1 & Klasifikasi Pembuluh Darah & 4 & 2,8 \\
2 & Normal & 74 & 52,5 \\
3 & PAP ringan & 49 & 34,8 \\
4 & PAP sedang & 14 & 9,9 \\
\hline
\end{tabular}

PAP merupakan penyakit yang ditandai dengan nyeri pada persendian yang menetap dan gangguan pergerakan. Namun, sebagian besar PAP juga dilaporkan tanpa gejala. Oleh karena itu, penyakit ini dapat diketahui dengan keluhan gangguan fungsi ekstremitas berupa iskemia pada bagian kaki yang memerlukan revaskularisasi yang baik.

PAP merupakan salah satu penyebab angka kesakitan dan kematian pada kasus kardiovaskuler dan penyakit diabetes melitus (Alahdab et al., 2015). PAP juga merupakan manifestasi umum dari arterosklerosis yang dihubungkan dengan gangguan kardiovaskular dan juga menjadi salah satu komplikasi diabetes melitus yang berujung pada amputasi kaki (Campia et al., 2019).

Penelitian ini menunjukkan bahwa nilai ABPI terbanyak berada pada kategori normal, yaitu sebanyak 52,5\%. Artinya, remaja memiliki aliran darah perifer yang baik atau tidak memiliki risiko PAP. Hal ini dapat disebabkan oleh kondisi vaskuler responden pada usia remaja masih memiliki elastisitas pembuluh darah yang masih baik dan komponen darah yang memungkinkan aliran darah mengalir dengan lancar.

Hal ini juga dapat disebabkan sebagian remaja memiliki aktivitas olahraga rutin yang menyebabkan kondisi kardiovaskuler menjadi baik yang berdampak pada aliran darah, termasuk aliran darah perifer.

PAP ditemukan seiring dengan pertambahan usia dan tertinggi pada usia di atas 40 tahun (Fowkes et al., 2017; Ostchega et al., 2007). Namun, pada penelitian ini ditemukan bahwa PAP juga berisiko terjadi pada usia remaja dengan angka yang cukup tinggi, yaitu 44,7\% terdiagnosa PAP ringan dan sedang. Kejadian ini dihubungkan dengan meningkatnya jumlah kejadian arteriosklerosis, hipertensi, dan diabetes melitus pada usia remaja.

Selain itu, penelitian ini juga mengidentifikasi $2,8 \% \quad$ responden mengalami kalsifikasi pembuluh darah. Kalsifikasi pembuluh darah merupakan kondisi di mana terbentuknya endapan mineral kalsium fosfat pada dinding pembuluh darah, khususnya di tunika intima dan media. Kalsifikasi pembuluh darah merupakan faktor penyebab terjadinya pengapuran pembuluh darah dan arteriosklerosis.

Peningkatan jumlah kejadian arteriosklerosis pada remaja diakibatkan oleh beberapa faktor, salah satunya yaitu faktor perubahan gaya hidup. Gaya hidup remaja di era revolusi industri 4.0 di mana terjadi rekayasa intelegensi dan internet of thing menjadi tulang punggung pergerakan dan konektivitas manusia dan mesin.

Hal tersebut berdampak pada menurunnya komunikasi langsung antar manusia, menurunkan pergerakan atau aktivitas fisik karena telah tergantikan oleh mesin. Akibatnya, terjadi penumpukan sisa-sisa metabolit pada pembuluh darah yang berdampak di bagian pembuluh darah seperti arteriosklerosis, diabetes melitus, serta penyakit arteri perifer. Perubahan gaya hidup yang dapat menyebabkan penyakit arteri perifer antara lain kebiasaan olahraga yang menurun, kebiasaan makan yang tidak sehat, merokok, dan lain sebagainya. 
Prevalensi Penyakit Arteri Perifer Berdasarkan Nilai Ankle-Brachial...

\section{Faktor Risiko PAP}

Faktor risiko PAP yang diidentifikasi pada penelitian ini adalah gaya hidup dan pola kebiasaan responden. Penelitian ini menemukan 95,7\% responden memiliki kebiasaan mengkonsumsi makanan asin; 99,3\% konsumsi makanan manis; 51,8\% minum kopi; 96,5 \% tidak merokok; dan $66,7 \%$ melakukan aktifitas fisik. Selain itu, penelitian ini juga menemukan bahwa $25,5 \%$ responden mengalami kram pada kaki setelah 5-15 menit duduk bersila (Tabel 4).

Makanan yang dikonsumsi setiap hari mempengaruhi proses metabolisme tubuh termasuk sisa metabolit. Jenis makanan berpengaruh secara signifikan terhadap kejadian hipertensi dan gangguan kardiovaskuler (Batmaro et al., 2019).

Kebiasaan makan yang tidak sehat seperti banyak mengonsumsi makanan yang berlemak tinggi, asin, tinggi karbohidrat, kurang makan sayur dan buah-buahan merupakan penyumbang terjadinya hipertensi. Asupan natrium terbukti menjadi faktor risiko yang berhubungan dengan kejadian hipertensi (Mahmudah et al., 2017).

Tabel 4. Faktor Risiko PAP

\begin{tabular}{|c|c|c|c|c|}
\hline No & Karakteristik & $\mathbf{F}$ & $\%$ & $p$ \\
\hline \multicolumn{5}{|c|}{ Konsumsi Asin } \\
\hline & & $\begin{array}{c}135 \\
6\end{array}$ & $\begin{array}{c}95,7 \\
4,3\end{array}$ & 0,730 \\
\hline
\end{tabular}

Konsumsi manis

1 Ya

2 Tidak

$140 \quad 99,3 \quad 0,823$

Konsumsi kopi

1 Ya

2 Tidak

$\begin{array}{lll}73 & 51,8 & 0,718\end{array}$

$68 \quad 48,2$

Merokok

1 Ya

$\begin{array}{lll}5 & 3,5 & 0,445\end{array}$

2 Tidak

13696,5

Aktivitas fisik

1 Ya

2 Tidak

$\begin{array}{lll}94 & 66,7 & 0,981\end{array}$

$47 \quad 33,3$

Aktivitas fisik

$1<5$ menit

2 5-15 menit

$\begin{array}{lll}30 & 21,3 & 0,265\end{array}$

315 - 30 menit

$36 \quad 25,5$

430 menit - 1 jam

$5>1$ jam

$35 \quad 24,8$

$\begin{array}{ll}24 & 17\end{array}$

$16 \quad 11,4$
Berdasarkan penelitian ini, dari 135 responden $(95,7 \%)$ yang mengonsumsi makanan asin, terdapat 61 responden yang terdiagnosis PAP ringan dan sedang serta 4 responden kalsifikasi pembuluh darah, sedangkan 6 responden yang tidak mengkonsumsi makanan asin 4 di antara nya memiliki nilai ABPI normal. Namun, hasil penelitian ini menunjukkan tidak ada hubungan yang signifikan antara konsumsi makanan asin dengan kejadian risiko PAP.

Makanan manis atau makanan tinggi karbohidrat merupakan salah satu pemicu terjadinya hipertensi dan diabetes melitus (Delima et al., 2009; Mahmudah et al., 2017). Diabetes melitus merupakan faktor determinan terjadinya penyakit jantung dan memiliki komplikasi berupa penyakit arteri perifer.

Pada penelitian ini didapatkan 140 responden $(99,3 \%)$ memiliki kebiasaan mengonsumsi makanan manis, 63 di antaranya memiliki kategori PAP ringan dan sedang serta 4 responden mengalami kalsifikasi pembuluh darah, sedangkan responden yang tidak mengkonsumsi makanan manis memiliki nilai ABPI normal. Namun, hasil analisis statistik menunjukkan tidak ada hubungan yang signifikan antara konsumsi makanan manis dan nilai ABPI.

Kopi merupakan salah satu minuman favorit yang telah lama dikonsumsi masyarakat, khususnya di Indonesia. Kopi sering diasosiasikan sebagai minuman para pria dan pekerja keras yang begadang pada malam hari. Kandungan yang terkandung dalam kopi yang utama adalah kafein. Kafein mempunyai efek dalam meningkatkan tekanan darah.

Kafein dapat berikatan pada reseptor adenosin yang akan mengaktifkan sistem saraf simpatik, lalu menyebabkan vasokonstriksi pada pembuluh darah. Beberapa penelitian yang telah ada menyebutkan bahwa konsumsi kopi dapat meningkatkan tekanan darah jika dikonsumsi berlebihan dalam 1 hari 
Prevalensi Penyakit Arteri Perifer Berdasarkan Nilai Ankle-Brachial...

(Kurniawaty \& Insan, 2016). Vasokonstriksi yang berlangsung lama ini dapat berdampak terhadap aliran darah terutama aliran darah perifer.

Pada penelitian ini ditemukan dari 73 responden $(51,8 \%)$ yang mengonsumsi kopi, terdapat 32 responden didiagnosis PAP ringan dan sedang serta 3 responden mengalami kalsifikasi pembuluh darah, sedangkan 68 responden $(48,2 \%)$ yang tidak mengonsumsi kopi didapatkan PAP ringan dan sedang sebanyak 31 responden dan 1 kalsifikasi. Berdasarkan analisis statistik tidak ada hubungan yang bermakna antara kebiasaan konsumsi kopi dengan nilai ABPI.

Merokok merupakan faktor risiko penyakit kardiovaskuler yang paling kompleks. Hal ini dikarenakan asap rokok mengandung kurang lebih 4000 bahan kimia yang berbeda (dengan berbagai ukuran). Bahan kimia ini selanjutnya dimodifikasi dalam tubuh manusia dengan sistem detoksifikasi (Messner \& Bernhard, 2014).

Kebiasaan merokok dipengaruhi oleh jumlah dan jenis bahan kimia asap yang terkandung dalam rokok. Di antara senyawa yang terkandung dalam rokok, kemungkinan besar bukan hanya satu atau kelas senyawa, seperti oksidan, yang menjadi faktor risiko terjadinya penyakit kardiovaskuler (Messner \& Bernhard, 2014). Dari penelitian ini diketahui bahwa 4 dari 5 responden yang memiliki kebiasaan merokok, terdiagnosis PAP ringan dan sedang.

Aktivitas fisik yang dilakukan secara teratur dan dengan jumlah yang terukur diketahui mampu meningkatkan kesehatan fisik, menjaga kebugaran bahkan dapat meningkatkan imun seseorang. Aktivitas fisik terbukti secara signifikan dapat mencegah kerusakan pembuluh darah seperti arteriosklerosis.

Seseorang yang melakukan aktivitas fisik secara rutin menurunkan kadar trigliserida, apolipo-protein B, meningkatkan high density lipoprotein
(HDL), perubahan ukuran partikel LDL, meningkatkan aktivitas aktivator plasminogen pada jaringan, dan menurunkan kadar kalsium pada arteri koroner. Selain itu, aktivitas fisik juga berpengaruh pada inflamasi dan ketebalan intima-media (Ahmed et al., 2012).

Hasil penelitian ini menunjukkan bahwa dari 94 responden $(66,7 \%)$ yang melakukan aktivitas fisik, 49 diantaranya memiliki nilai ABPI normal dibandingkan yang tidak melakukan aktivitas fisik, sedangkan yang mengalami PAP ringan dan sedang masing-masing 42 dan 21 responden. Berdasarkan hasil uji statistik tidak didapatkan hubungan yang bermakna antara aktivitas fisik dan nilai ABPI.

Berdasarkan penelitian ini, faktor risiko seperti mengkonsumsi makanan asin, makanan manis, minum kopi, dan merokok berlebihan serta aktivitas fisik yang kurang dapat menurunkan nilai ABPI atau menjadi faktor risiko terjadinya penyakit arteri perifer. Namun, faktor risiko tersebut tidak menunjukkan hubungan yang bermakna secara statistik terhadap nilai ABPI atau kejadian penyakit arteri perifer pada remaja.

Hal ini dapat disebabkan oleh jumlah dan heterogenitas responden yang berasal dari berbagai macam latar belakang serta keterbatasan kuesioner yang digunakan.

\section{PENUTUP}

Prevalensi penyakit arteri perifer (PAP) pada remaja sebanyak 44,7\%. Berbagai faktor risiko dapat menjadi penyebab PAP. Penelitian ini menunjukkan bahwa kebiasaan mengkonsumsi makanan asin, makanan manis, minum kopi berlebih, dan kebiasaan merokok serta aktivitas fisik yang kurang, dapat menurunkan nilai ABPI atau menjadi faktor risiko terjadinya penyakit arteri perifer.

Walaupun demikian, secara statistik faktor risiko tersebut tidak memiliki 
Prevalensi Penyakit Arteri Perifer Berdasarkan Nilai Ankle-Brachial...

hubungan yang bermakna. Bagi peneliti selanjutnya, diharapkan dapat mengembangkan penelitian faktor risiko terjadinya penyakit arteri perifer dengan memodifikasi kuesioner dan homogenitas responden sehingga faktor - faktor perancu penelitian dapat dieliminasi.

\section{UCAPAN TERIMA KASIH}

Ucapan terima kasih kepada Fakultas Kedokteran Universitas Mulawarman yang telah memberikan dana hibah pada penelitian ini, sehingga penelitian ini dapat dilaksanakan.

\section{DAFTAR PUSTAKA}

Ahmed, H. M., Blaha, M. J., Nasir, K., Rivera, J. J., \& Blumenthal, R. S. (2012). Effects of Physical Activity on Cardiovascular Disease. The American Journal of Cardiology, 109(2), 288-295. https://doi.org/10.1016/j.amjcard. 2011.08.042

Alahdab, F., Wang, A. T., Elraiyah, T. A., Malgor, R. D., Rizvi, A. Z., Lane, M. A., Prokop, L. J., Montori, V. M., Conte, M. S., \& Murad, M. H. (2015). A systematic review for the screening for peripheral arterial disease in asymptomatic patients. Journal of Vascular Surgery, 61(3), 42S-53S. https:// doi.org/10.1016/j.jvs.2014.12.008

Batmaro, R. K., Hondo, F., \& Malinti, E. (2019). Hubungan Jenis Makanan Dan Tekanan Darah Wanita Dewasa Hipertensi. Nutrix Journal, 3(2), 38. https://doi.org/10.37771/ nj.Vol3.Iss2.403

Blanes, J. I., Cairols, M. A., Marrugat, J., \& ESTIME. (2009). Prevalence of peripheral artery disease and its associated risk factors in Spain: The ESTIME Study. International Angiology: A Journal of the International Union of Angiology, 28(1), 20-25. http:// www.ncbi.nlm.nih.gov/pubmed/ 19190551

Campia, U., Gerhard-Herman, M., Piazza, G., \& Goldhaber, S. Z. (2019).
Peripheral Artery Disease: Past, Present, and Future. The American Journal of Medicine, 132(10), 1133-1141. https://doi.org/10.1016/j.amjmed. 2019.04.043

Conte, S. M., \& Vale, P. R. (2018). Peripheral Arterial Disease. Heart, Lung and Circulation, 27(4), 427-432. https://doi.org/10.1016/j.hlc. 2017.10.014

Criqui, M. H., \& Aboyans, V. (2015). Epidemiology of Peripheral Artery Disease. Circulation Research, 116(9), 1509-1526. https://doi.org/10.1161/ CIRCRESAHA.116.303849

Delima, D., Mihardja, L., \& Siswoyo, H. (2009). Prevalensi dan Faktor Determinan Penyakit Jantung di Indonesia. Buletin Penelitian Kesehatan, 37(3), 142-159. http:// ejournal.litbang.kemkes.go.id/ index.php/BPK/article/view/2182

Fowkes, F. G. R., Aboyans, V., Fowkes, F. J. I., McDermott, M. M., Sampson, U. K. A., \& Criqui, M. H. (2017). Peripheral artery disease: epidemiology and global perspectives. Nature Reviews Cardiology, 14(3), 156-170. https:// doi.org/10.1038/nrcardio.2016.179

Kurniawaty, E., \& Insan, A. N. M. (2016). Pengaruh kopi terhadap hipertensi. Medical Journal of Lampung Univeersity, 5(2), 6-10. http:// juke.kedokteran.unila.ac.id/index.php/ majority/article/view/1069

Mahmudah, S., Maryusman, T., Arini, F. A., \& Malkan, I. (2017). Hubungan Gaya Hidup Dan Pola Makan Dengan Kejadian Hipertensi Pada Lansia Di Kelurahan Sawangan Baru Kota Depok Tahun 2015. Biomedika, 8(2), 4351. https://doi.org/10.23917/ biomedika.v8i2.2915

Messner, B., \& Bernhard, D. (2014). Smoking and Cardiovascular Disease. Arteriosclerosis, Thrombosis, and Vascular Biology, 34(3), 509-515. https:// doi.org/10.1161/ATVBAHA. 
113.300156

Ostchega, Y., Paulose-Ram, R., Dillon, C. F., Gu, Q., \& Hughes, J. P. (2007). Prevalence of Peripheral Arterial Disease and Risk Factors in Persons Aged 60 and Older: Data from the National Health and Nutrition Examination Survey 1999â\&\#128;\&\#147;2004. Journal of the American Geriatrics Society, 55(4), 583589. https://doi.org/10.1111/j.15325415.2007.01123.x

Sartipy, F., Sigvant, B., Lundin, F., \& Wahlberg, E. (2018). Ten Year Mortality in Different Peripheral Arterial Disease Stages: A Population Based Observational Study on Outcome. European Journal of Vascular and Endovascular Surgery, 55(4), 529536. https://doi.org/10.1016/j.ejvs. 2018.01.019

Selvin, E., \& Erlinger, T. P. (2004). Prevalence of and Risk Factors for Peripheral Arterial Disease in the United States. Circulation, 110(6), 738743. https://doi.org/10.1161/01.CIR. 0000137913.26087.F0
Sibley III, R. C., Reis, S. P., MacFarlane, J. J., Reddick, M. A., Kalva, S. P., \& Sutphin, P. D. (2017). Noninvasive Physiologic Vascular Studies: A Guide to Diagnosing Peripheral Arterial Disease. RadioGraphics, 37(1), 346-357. https://doi.org/10.1148/rg.2017160044

Velescu, A., Clara, A., Martí, R., Ramos, R., Perez-Fernandez, S., Marcos, L., Grau, M., Degano, I. R., Marrugat, J., \& Elosua, R. (2017). Abnormally High Ankle-Brachial Index is Associated with All-cause and Cardiovascular Mortality: The REGICOR Study. European Journal of Vascular and Endovascular Surgery, 54(3), 370-377. https://doi.org/10.1016/j.ejvs. 2017.06.002

Weragoda, J., Seneviratne, R., Weerasinghe, M. C., \& Wijeyaratne, S. M. (2016). ABPI against Colour Duplex Scan: A Screening Tool for Detection of Peripheral Arterial Disease in Low Resource Setting Approach to Validation. International Journal of Vascular Medicine, 2016, 1-5. https://doi.org/10.1155/2016/1390475 